\title{
Rapid Decision Making on the Fire Ground
}

\author{
Gary A. Klein, Roberta Calderwood, \\ and Anne Clinton-Cirocco \\ Klein Associates, Inc.
}

\begin{abstract}
Battlefield Information Systems Technical Area
Franklin L. Moses, Chief
\end{abstract}

\section{Systems Research Laboratory \\ Robin L. Keesee, Director}

U.S. ARMY RESEARCH INSTITUTE FOR THE BEHAVIORAL AND SOCIAL SCIENCES

5001 Eisenhower Avenue, Alexandria, Virginia 22333-5600

Office, Deputy Chief of Staff for Personnel

Department of the Army

June 1988

Approved for public release; distribution unlimited. 